\title{
A GAZDASÁGI TÁRSASÁGOK ADÓTERHÉT BEFOLYÁSOLÓ TÉNYEZŐK VIZSGÁLATA
}

\section{EXAMINATION OF THE FACTORS AFFECTING THE TAX BURDEN ON ECONOMIC COMPANIES}

\author{
Kolber Kitti ${ }^{1}$, Dr. habil. Parádi-Dolgos Anett ${ }^{1}$, Koroseczné Dr. Pavlin Rita ${ }^{1}$ \\ ${ }^{1}$ Pénzügy és Számvitel Intézet, Gazdaságtudományi Kar, Kaposvári Egyetem, Magyarország
}

\author{
Kulcsszavak: \\ vállalati adó \\ adókedvezmény \\ területi koncentráció
}

Keywords:

corporate tax

tax benefit

territorial concentration

\begin{abstract}
Összefoglalás
A vállalkozások széles körének megadóztatása komoly kihívást jelent napjaink gazdasági, társadalmi életében. A tanulmány aktualitását jelzi, hogy az elmúlt években hazánk adózási rendszerében átalakítások zajlottak le. A kutatás során a vállalatokat érintő nyereségadó teher mértékét az adókedvezmények figyelembevételével analizáljuk.

A vállalati szektor adatait három oldalról közelítve vizsgáljuk, melynek során statisztikailag igazolható kapcsolatokat keresünk az adózás elötti eredmény, az igénybevett adókedvezmények és a fizetendő adó között. Megvizsgáljuk, hogy a vállalkozások adóterhében milyen regionális, illetve település szerinti differencia lelhetö fel.

Az adóbevételek területi megoszlása erösen koncentrált. Felmerül a kérdés, hogy vajon milyen mértékben befolyásolja a térség fejlettsége az igénybevett adókedvezmények arányát.

Az eredményeinkben településenként és vállalkozásonként lényeges eltérés tapasztalható a vállalkozások társasági adóterhében.
\end{abstract}

EFOP-3.6.2-16-2017-OOO18 "Termeljünk együtt a természettel! - Az agrárerdészet, mint új kitörési lehetőség"

\begin{abstract}
Taxing a wide range of businesses is a signify major challenge in nowadays economic, social life. The topicality of the study is indicated by the fact that the Hungarian tax system has been transformed in recent years. We analyze by respect to tax benefits the extent of the tax burden at companies in the course of the research. The enterprise sector data are examined from three sides whereby we search for statistically verifiable relationships between the pre-tax profit, the tax benefits used and the tax payable. We investigate what regional and settlement differences can be located in the tax burden of businesses. Tax revenue appears to be highly concentrated by territorial distribution. The question arises to what extent the development of the region influences the proportion of the tax benefits used. In our results, there is a significant difference experienced in the corporate tax burden on enterprises of settlement.
\end{abstract}




\section{Bevezetés}

Az elmúlt időszak gazdaságpolitikai intézkedései úgy, mint a kedvező hitelpolitikai intézkedések- a beruházásokat ösztönző, keresletnövelő - jelentős hatással vannak a települések fejlesztésére, a vállalkozások eredményességére. Ennek köszönhetően az adóbevételek is növekedtek, de településenként eltérő mértékben.

A társasági adózás törvényi szabályozása jelentős módosításokon esett át az elmúlt években, ennek köszönhetően 2017-től megszűnt a sávos adókulcs alkalmazása, helyette csökkentett, egységes 9 \%os adókulcsot alkalmazunk. Ugyanakkor az effektív adókulcs ettől lényegesen eltérhet, hiszen az adókedvezmények köre széles. Az ok-okozati összefüggéseket a vállalatok adófizetésében mérjük a befolyásoló paraméterek segítségével, mint adózás előtti eredmény, adókedvezmények. Az adathalmazunk elemei közötti kapcsolatok szorosságát regionális, megyei és települési szinten számszerüsítjük. Tanulmányunk célja, hogy átfogó elemzést készítsünk a települési szintű társasági adóteherről ezek tükrében.

\subsection{A témához kapcsolódó szakirodalom}

A "jó" adórendszer fo" eleme, hogy hatékony legyen, azaz az állam tervezett adóbevételei a legnagyobb mértékben bevételként mutatkozzanak, miközben a gazdasági szereplők vállalkozói tevékenységét nem torzítják [8]. A torzítás alatt a gazdasági tevékenységük korlátozását (nagymértékű terhek fizetése) az adóelkerülést vagy az adóoptimalizálást tekintjük. A vállalkozások számára fontos, hogy ne helyezzen túlzott adminisztratív terheket (adóbevallás és ügyintézés) az adózók számára, mely további költségeket, terhet ró a szektorra. Ezek alapján az adórendszer hatékonyságát további tényezők szerint határozhatjuk meg: egyszerünek, átláthatónak, kiszámíthatónak és igazságosnak kell lennie [5].

A célravezető állami beavatkozással, olyan adórendszert alakítottak ki hazánkban, ahol 2013-tól nagyobb górcső alá vonták a kisvállalkozásokat is. Hiszen egy állam, akkor avatkozik be ideálisan, ha a gazdasági növekedés hatékonysága mellett kedvezőbb feltételekkel adóztatja meg a kis- és középvállalkozási szektort a nagyobb termelékenységgel bíró nagyvállalatokkal szemben [7]. A társasági adózásról szóló 1996. LXXXI törvény módosításával megszűntették a sávos adókulcs alkalmazását, majd 2017. január 1-től egységes 9\%-os adókulcsot alkalmazunk [1][3].

$\mathrm{Az}$ adózás rendjéről szóló 2003.XCII. törvényt módosító 2017.CL. és a társasági adózásra vonatkozó törvényben rögzítettek szerint állapítjuk meg tételesen a társasági adónk alapját [2][3]. Az adózás előtti eredmény szükséges a társasági adóalap megállapításához. Számviteli szempont szerint az adóalapot csökkentő tételeket az eredményünkből levonjuk, míg a növelő tételeket hozzáadjuk. A társasági adóalapunk szerinti adókulccsal meghatározzuk a számított adónkat, melyből levonjuk az összes elszámolt adókedvezményeket illetve a külföldön megfizetett adókat. Ezek alapján állapítjuk meg a vállalkozásunk fizetendő adóját [6].

Az utóbbi években a gazdaságpolitikai beavatkozások hatására fokozatosan stabilizálódott az adókedvezmények rendszere. A vállalkozásoknak a következő beruházások üzembe helyezése illetve üzemeltetése esetén igényelhető a fejlesztési adókedvezmény, mely kritériumokban megfelel a beruházás:

- $\quad$ a jelenértéken legalább 3 milliárd forint értékű beruházás;

- $\quad$ meghatározott kedvezményezett települési önkormányzat közigazgatási területén üzembe helyezett és üzemeltetett, jelenértéken legalább 1 milliárd forint értékű beruházás;

- jelenértéken legalább 100 millió forint értékű, korábban már használatba vett, állati eredetű élelmiszert előállító létesítmény élelmiszer-higiéniai feltételeinek megteremtését szolgáló beruházás; - jelenértéken legalább 100 millió forint értékű önálló környezetvédelmi beruházás;

- $\quad$ a jelenértéken legalább 100 millió forint értékü, az alapkutatást, az alkalmazott kutatást vagy a kísérleti fejlesztést szolgáló beruházás;

- jelenértéken legalább 100 millió forint értékű, kizárólag film- és videógyártást szolgáló beruházás;

- $\quad$ munkahelyteremtést szolgáló beruházás;

- $\quad$ jelenértéken legalább 500 millió forint értékű, kis- és középvállalkozás által megvalósított beruházás;

- $\quad$ szabad vállalkozási zóna területén üzembe helyezett és üzemeltetett, jelenértéken legalább 100 millió forint értékủ beruházás. 
A fejlesztési adókedvezmény a számított társasági adó maximum 80 százalékig vehető igénybe. Egyéb adókedvezményeket a vállalkozások a fejlesztési adókedvezménnyel csökkentett adó maximum 70 százalékáig alkalmazhatják [4]. igénybe:

A kis- és középvállalkozások alábbi adó-, adóalapot csökkentő kedvezményeket vehetnek

Tárgyi eszközök beszerzéséhez, előállításához, pénzügyi intézménytől igénybevett beruházási hitel utáni kamatok adókedvezménye vehető igénybe. A kisvállalkozások adókedvezmény mértéke maga a hitel kamata.

További adókedvezmények vehetők igénybe: energiahatékonysági célokat szolgáló beruházásokra, élőzenei szolgáltatások költségeire, látványcsapat-sportok; filmgyártás- és előadóművészeti szervezet támogatására valamint a szövetkezeti közösségi alap-képzésére [3].

\section{A felhasznált adatok és alkalmazott módszerek}

A vizsgálatunkhoz az Országos Területfejlesztési és Területrendezési Információs (továbbiakban: TEIR) rendszer adatbázisából töltöttük le adatainkat. A rendszerben elérhető információkat a Nemzeti Adó- és Vámhivatal tette közzé. 2014-2017 között minden magyarországi települést $(\mathrm{N}=3155)$, megyei $(\mathrm{N}=19)$ és regionális $(\mathrm{N}=8)$ szinten is szétbontottuk az adathalmazt. Az adatbázisunkban szerepel az adott évre vonatkozó településenkénti fizetendő adó, adózás előtti eredmény, összes adókedvezmény, fejlesztési adókedvezmény és a vállalkozások száma.

A megfelelő adattisztítás után a vállalkozások közötti adóteher eltérését regionális, megyei és település szinten is kimutattuk. A vizsgálatba nem vontuk be a fővárost, mert a kiugróan magas adatok torzítják az adathalmazunkat.

A települési és megyei szinten a fizetendő adókat összesítettük évek szerint, majd megyei vonatkozásban megvizsgáltuk az adott évi egy vállalatra jutó fizetendő adó nagyságát. A változó azt mutatja meg, hogy településenként mekkora társasági adóbevételt realizáltak a vállalatok átlagosan.

Végül a vállalatok által igénybevett adókedvezmény arányát állapítottuk meg település, majd megyei szinten és az igénybevett adókedvezmények megoszlását az összes adókedvezmény/számított adó mutatóval fejeztük ki a vizsgált években.

Regresszió analízis segítségével vizsgáltuk, hogy mennyiben befolyásolja a fizetendő adó alakulását az adózás előtti eredmény illetve az adókedvezmények mértéke. Egyrészt az adott évi megyei összes fizetendő adó alakulását, mint eredmény változónkat az összes adókedvezmény függvényében analizáltuk, másrészt a fizetendő adó és az adózás előtti eredmény közötti összefüggését állapítottuk meg megyéink adataiban.

\section{A kutatási eredmények}

Az első részben a vállalkozások által fizetendő adó és az adózás előtti eredmények közötti kapcsolatot vizsgáltuk, majd a fizetendő adó és az igénybevett összes adókedvezmények korrelációját elemeztük, hogy milyen mértékü az összefüggés megyéinkben a vizsgált években. A regresszió analízis számítása során azt vizsgáltuk, hogyan függ össze az eredményváltozónk, a fizetendő adó és az adózás előtti eredmény, mint magyarázó változónk. A regresszióból kapott eredményeinket lineáris regressziós függvény segítségével ábrázoltuk, ami megmutatja, hogy a fizetendő adó és az adózás elótti eredmény közötti kapcsolat összefüggése milyen irányú korrelációt mutat az adatok alapján. A regressziós statisztikai elemzéssel prezentáltuk a korrelációs együtthatónkat, az $r$ eredményeit. Az együttható a fizetendő adó, adózás előtti eredmény és az összes igénybevett adókedvezmény közötti kapcsolat szorosságáról ad információt. $R^{2}$ determinációs együttható segítségével pedig meghatározzuk az együttható változók között, az adózás előtti eredmény illetve az összes adókedvezmény hány százalékban magyarázzák a fizetendő adó nagyságát.

A vizsgált években regresszió analízis segítségével meghatároztuk a változók közötti kapcsolatok szorosságát. A regresszió analízis elemzése során a fizetendő adó és az adózás előtti eredmény közötti kapcsolat szignifikanciáját a kapott eredményeinkben bizonyítottuk.

A 2014-2017 években a fizetendő adó és az adózás előtti eredmény között igazoltan szignifikáns kapcsolat van, minden eredményük azt igazolta, hogy 2014. és 2015. évben a változók szoros és sztochasztikus kapcsolatban vannak, 2016. és 2017. évben a változók között jóval szorosabb és sztochasztikusabb a kapcsolat. Továbbá, itt számításba kell venni, hogy az adóalapot csökkentő és 
növelő tételek, az igénybevett adókedvezmények vállalkozásonként és tevékenységenként, méretkategóriánként eltérő, mely az évenkénti eredményünkben lévő kiugró különbségeket eredményezi. A másik oldalról megközelítve pedig a sávos adózást felváltó lineáris adókulcs esetén az adózás előtti eredményünket módosító tételekkel meghatározott társasági adóalapot egységes mértékben terheli a társasági adókulcs 2017-től. Lineáris regresszió függvényekkel ábrázoltuk (1. ábra) a megyénként realizált adóbevételek eloszlását, ezt tekintve néhány kiugró adat megmutatja, hogy a fejlettebb régiókban a vállalkozások teljesítménye területileg koncentráltabb.

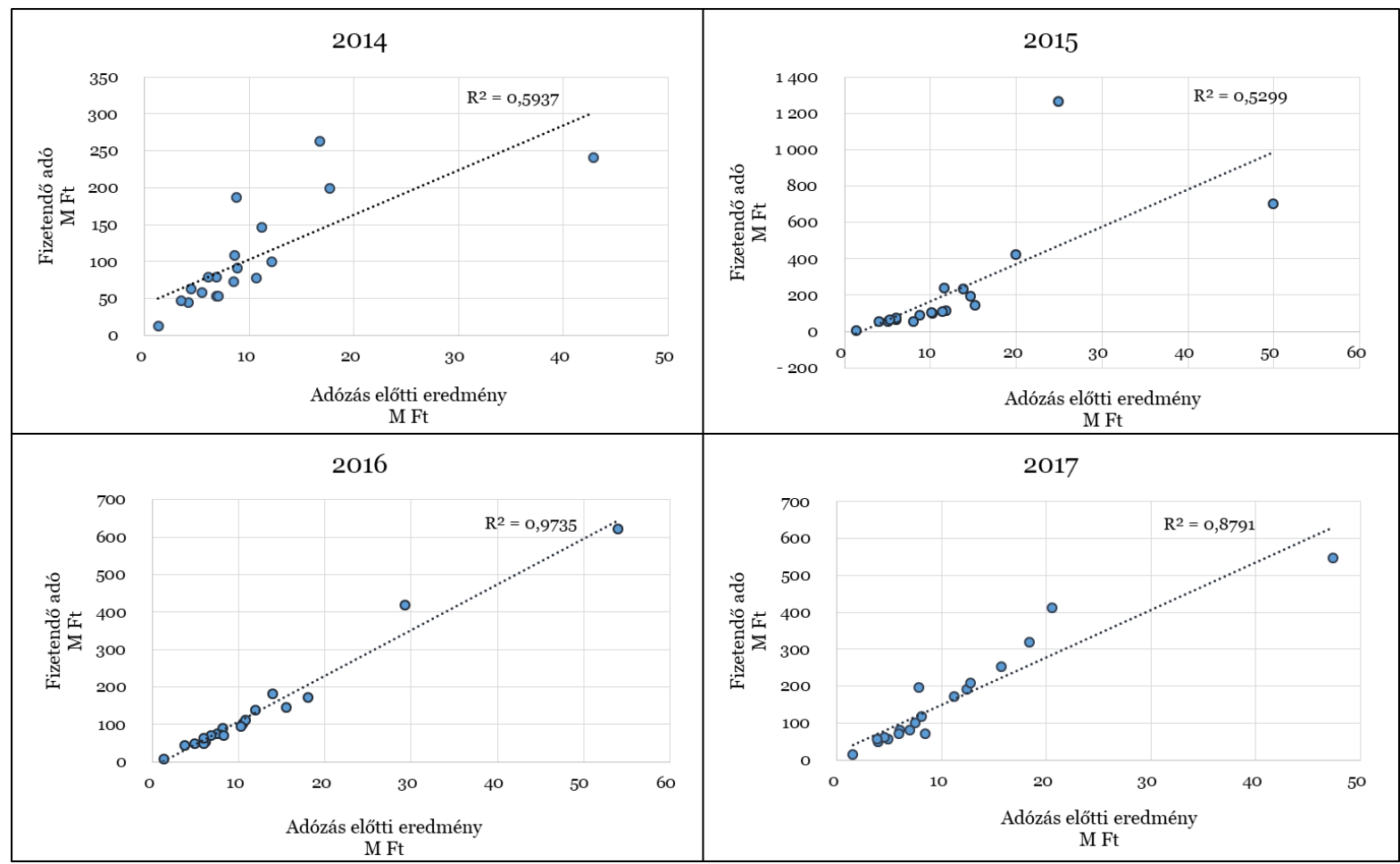

1. ábra. A fizetendő adó alakulása az adózás elötti eredmény függvényében (2014 - 2017)

A regressziós vizsgálatok során kapott eredményeknél - mindkét vizsgálati struktúrábanfigyelembe vettük a következő tényezőket is. A gazdasági növekedés érdekében a vállalkozói szférába közvetlen bevezetésre került 2013. január 1-től kisvállalati adók (KATA, KIVA) befolyással bírtak a társasági adó bevételekre. A 2014-es évben a kisadózók számára fizetendő tételes adó szabályai még kedvezóbbek lettek, az adókedvezmény a beruházási hitelek kamatainak 60\%-ával csökkenthetik társasági adóalapjukat. A 2017. január 1-től hatályos adózásra vonatkozó szabályok módosultak. A társasági adózás egységes adókulcson alapulva 9\%-ra módosult.

A regresszió elemzés második szakaszában az előző módszerrel azonosan a fizetendő adó és az összes igénybevett kedvezmény közötti szignifikáns kapcsolatot vizsgáltuk. A 2. ábrával szemléltetjük a lineáris regressziót megyéink eredményeiben 2014-2017 közötti időszakban, a fizetendő adó és az összes igénybevett adókedvezmény között. 


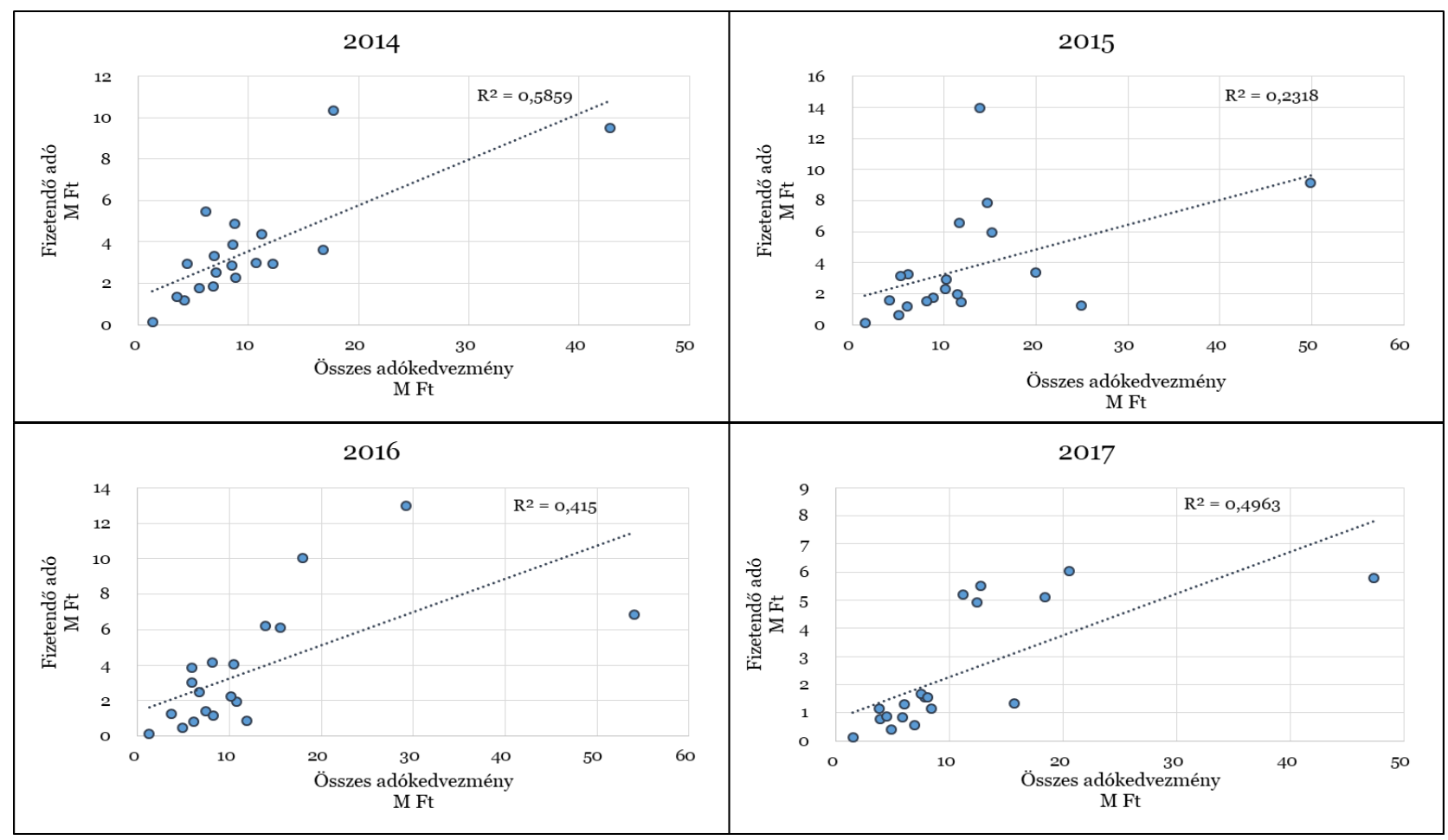

2. ábra. A fizetendő adó alakulása az összes adókedvezmény függvényében (2014 - 2017)

Ebben a vizsgálati időszakban is azt tapasztaltuk, hogy a fizetendő adó és az adókedvezmények között igazoltan szignifikáns kapcsolat van, hiszen a vizsgált változók 2014. évben szoros, míg 2015., 2016., 2017. években közepes sztochasztikus a kapcsolat. Az eredményeink tükrében itt is figyelembe vettük, hogy a fizetendő adó megállapításánál az igénybevett adókedvezmények közvetlen kapcsolatban állnak egymással, míg itt is a méretkategória, vállalkozásonként és tevékenységi körök szerinti megoszlástól eltekintettünk.

Az elemzés harmadik szakaszában az egy vállalatra jutó fizetendő adó mutató eredményeit elemeztük. A vizsgált időszakban jelentős területi egyenlőtlenségeket tapasztalhattunk a fizetendő adó eloszlásában is, melyet a 3. ábra szemléltet.

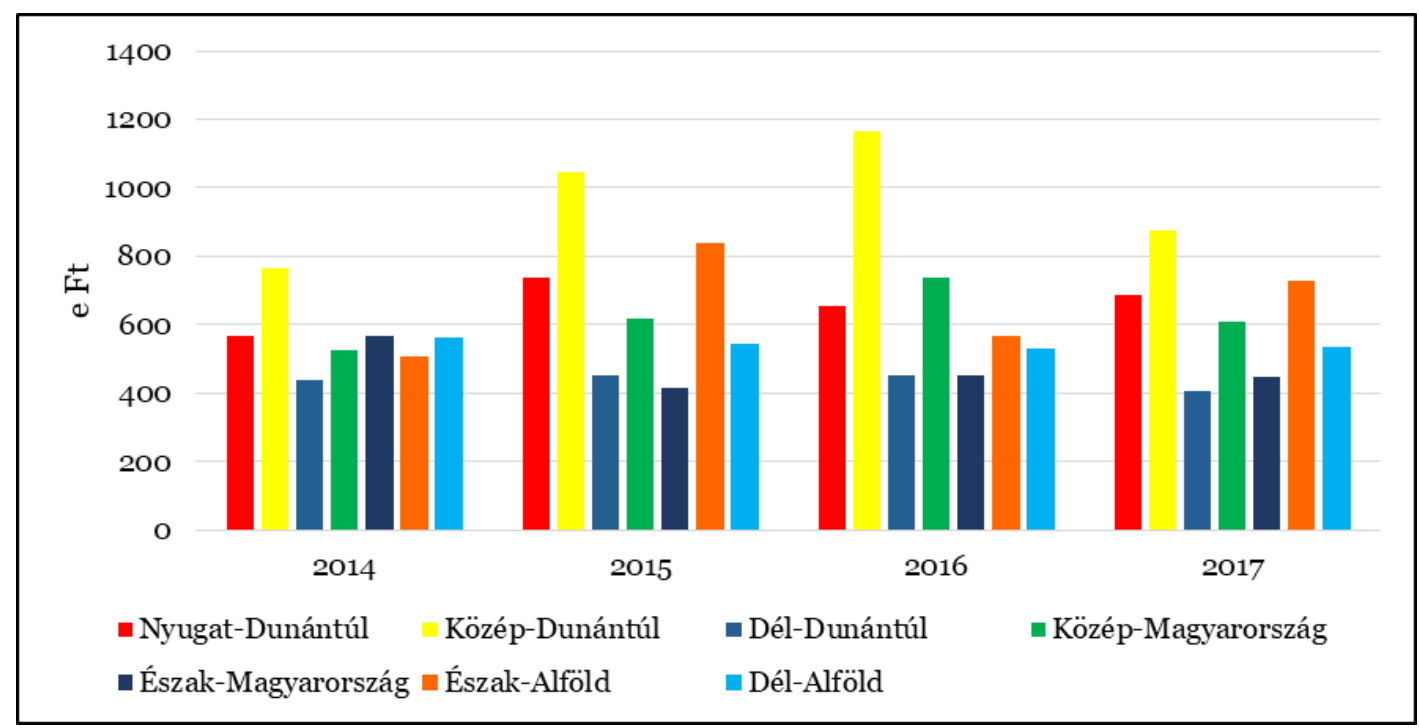

3. ábra. Az egy vállalatra jutó fizetendő adó alakulása (2014-2017)

Látható, hogy a Közép-Dunántúli régió megyéiben mindegyik évben a legnagyobb az egy vállalatra jutó fizetendő adó nagysága, a vállalkozások számának növekedésével arányosan 
kimagasló teljesítményük. A legelmaradottabb térségek, a Dél-Dunántúli- és Észak-Magyarország régió megyéi. A vállalkozások számának intenzitásával egyenes arányban van a vállalkozásokra jutó fizetendő adó nagysága is. Az adatok jól mutatják, hogy a területileg fejlettebb régiókban magasabb a vállalati fizetendő társasági adó volumen. A legnagyobb egy vállalatra jutó fizetendő adóval Fejér megye rendelkezett 2016. évben, ahol átlagosan településenként egy vállalat $1297000 \mathrm{Ft}$ adót teljesített az adóévben, míg Nógrád megyében ezzel szemben csupán 287000 Ft adófizetés jutott egy vállalatra.

A 4. ábrán az igénybevett adókedvezmények számított adóhoz viszonyított arányát szemléltettük.

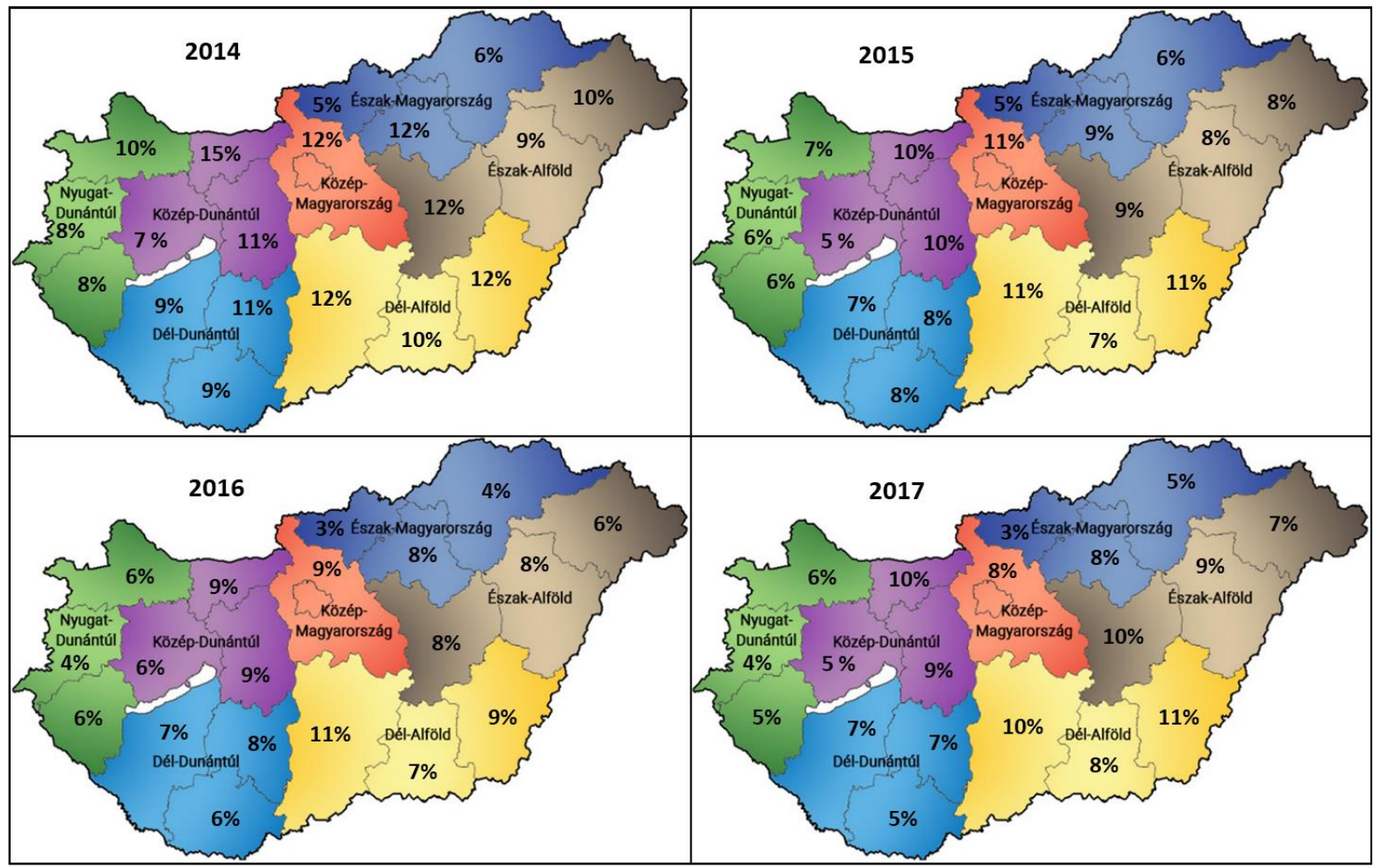

\section{4. ábra. Az igénybevett adókedvezmények számított adóhoz viszonyított aránya megyék szerint} (2014-2017)

A 2014-2017 időszakban szintén megyék szerint összesítettük, hogy milyen arányban veszi igénybe a vállalkozói szektor a kedvezményeket a társasági adózás szempontjából. Az eredmények jól tükrözik, hogy 2017-re folyamatosan emelkedő tendenciát mutat az igénybevevők aránya országosan. A törvényben meghatározott feltételek szerint csökkentik adófizetési kötelezettségeiket a vállalkozói szférában hatékonyan müködő vállalkozások. Az adott vállalkozások tevékenységi körének esetleges bővítése befolyásolja az adott évben mennyi adókedvezményt vettek igénybe a vállalkozások, illetve milyen jellegü beruházást valósítottak meg hitelből. A társasági adózásról szóló törvényt minden évben módosították, a vállalkozásoknak folyamatosan szélesedő adókedvezmények tárházát biztosítják, mellyel a számított adójukat redukálják. Az állam direkt kormányzati beavatkozásokkal elsősorban a kis- és középvállalkozásoknak nyújt alternatívát, de minél nagyobb beruházást végez egy vállalkozás, azzal további gazdasági növekedést tud realizálni.

\section{Következtetések}

A tanulmányunkban azt vizsgáltuk, hogy 2014 és 2017 között hogyan változtak az adóterhek az igénybevett adókedvezmény tükrében a társasági adófizetés szemszögéből. A fizetendő adó, az adózás előtti eredmény és az összes igénybevett adókedvezmény közötti szignifikáns kapcsolat statisztikailag igazolható. A kapott eredmények igazolták, hogy területenként, megyénként és régiónként is eltérő az adóterhek nagysága és erősen koncentráltak, így lényeges eltérés tapasztalható az egy vállalkozásra jutó adóteherben. 
Az egy vállalatra jutó fizetendő adóra vonatkozóan, területileg kiugró szórás különbségeket tapasztaltunk. Területi megoszlás szerint a fejlettebb régiókba és a megyeszékhelyek köré összpontosul a vállalati szektor legnagyobb hányada, ahol jellemzően nagyobb adózás előtti eredményt realizálnak. A kormány további támogatóprogramjában a KKV-k támogatása mellett, az igénybe vehető adókedvezmények körét is kiszélesítette azzal a céllal, hogy a vállalkozások versenyképességének növelésén keresztül biztosítsa a gazdasági növekedést.

\section{Irodalomjegyzék}

[1] 1996. évi LXXXI. társasági adózásról szóló törvény

[2] 2003. évi XCII. adózás rendjéről szóló törvény

[3] 2017. évi CL. adózás rendjéről szóló törvény

[4] A fejlesztési adókedvezményről szóló 165/2014 (VII.17.) kormányrendelet

[5] Bary László - Gyenge Magdolna - Joó Âgnes - Lakatos László Péter (2014): Adózási ismeretek 2014. Magyar Könyvvizsgálói Kamara, Budapest.

[6] Elek Péter -Lőrincz László (2015): Az effektív társasági adókulcs rugalmassága Magyarországon a 2009-2011 közötti adókulcscsökkentés alapján. Közgazdasági Szemle, 62 (1)

[7] Erdős Tibor (2014): Az adózás, a hatékonyság és a gazdasági növekedés kapcsolatának néhány elméleti problémája, Közgazdasági Szemle, 61 (Klnsz). pp. 1-76.

[8] Scharle Ágota - Benczúr Péter - Kátay Gábor - Váradi Balázs (2010): Hogyan növelhető az adórendszer hatékonysága?, MNB tanulmányok 88. 